تحليل عدم قطعيت در براورد خسارت مورد انتظار ساليانه بهمنظور ارزيابى ريسك سيلاب (مطالعه موردى: دشت كوهيايه - سخزى از حوضه آبريز زايندهرود)

نر گس عليان، محمدمهدى احمدى" و بهرام بختيارى'

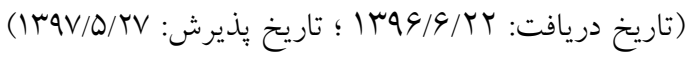

جكيده

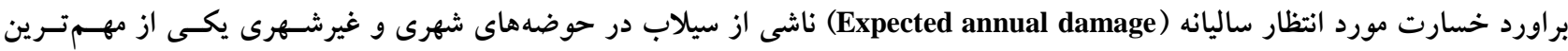

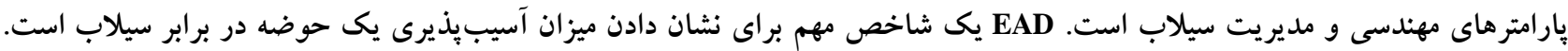

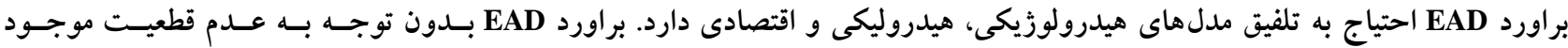

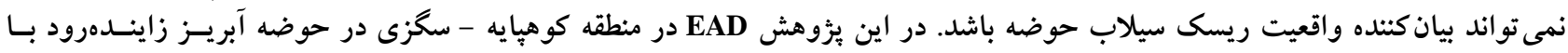

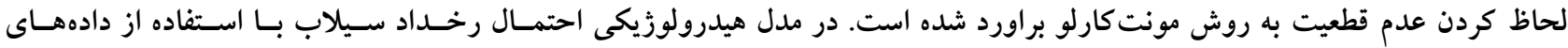

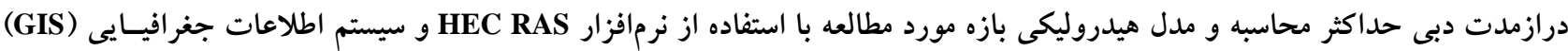

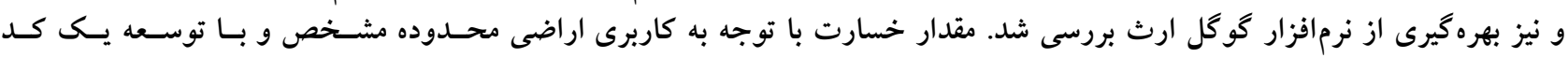

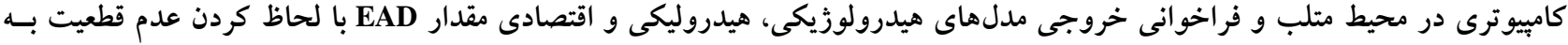

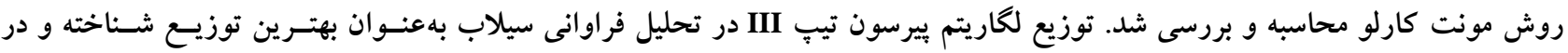

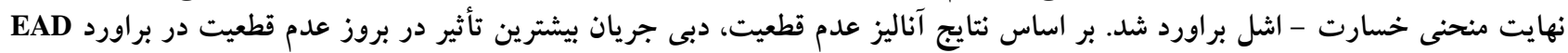

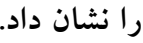

وازههاى كليدى: تحليل ريسك، خسارت سيل، GIS HEC-RAS، عدم قطعيت، منطقه كوهيايه - سخزى، زايندهرود

ا. كروه علوم و مهندسى آب، دانشكده كشاورزى، دانشخاه شهيد باهنر كرمان، كرمان، ايران

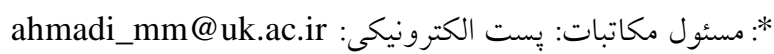


مدل سازى خسارت سيل با تجزيه و تحليل منابع عـدماطمينـان بـه

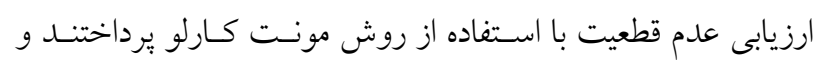

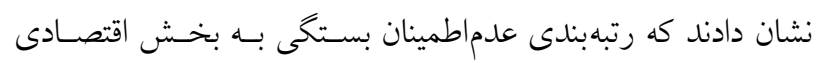
(مسكن خصوصى، زمين كشاورزى و فعاليتهاى اقتصادى) دارد و

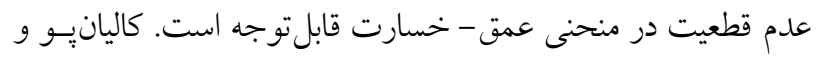

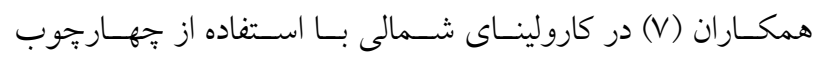
مونت كارلو به تجزيه و تحليل عدم قطعيت يرداختند و نتايج نشـان

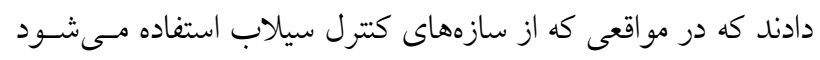

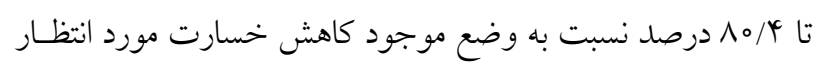

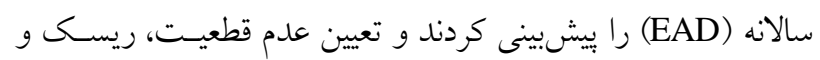

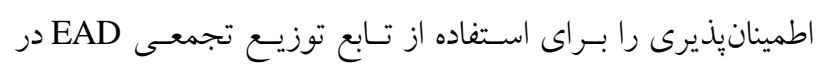
تحليل ها ضرورى دانستند. خسارت ناشى از سيل شامل خسارات محسـوس و خسـارات نامحسوس است كه خود خسارات محسوس به دو دسته خسارات

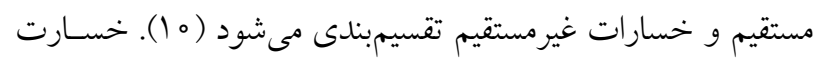

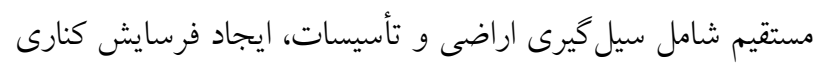

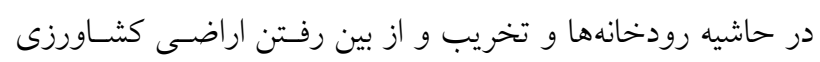

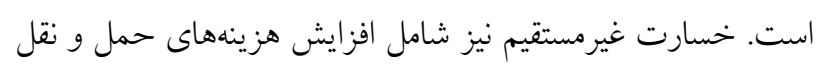

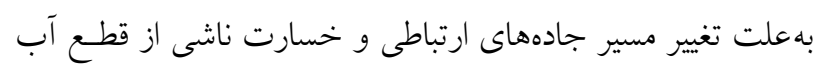

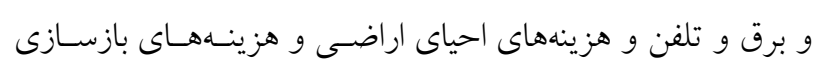

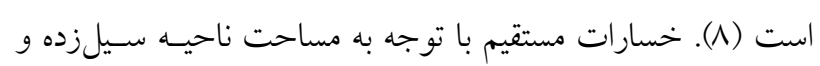

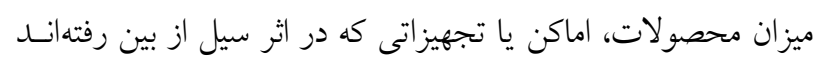

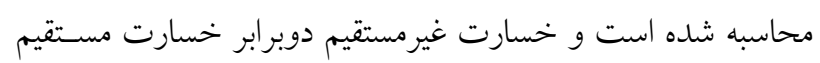
در نظر كرفته شده است.

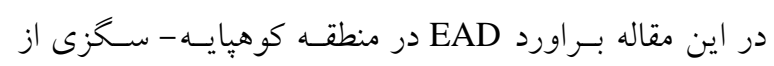

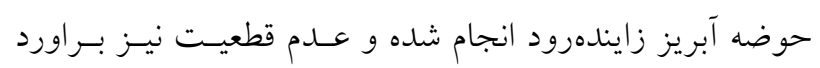

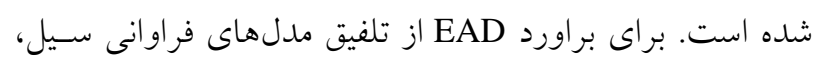
مشخصات هيدروليكى و براورد اقتصادى استفاده شده است.

\section{مواد و روشها - ماد \\ منطقه مورد مطالعه}

حوضه آبريز زايندهرود با مساحتى حدود $1991 V$ كيلومتر مربـع

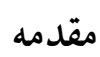

بديده سيلاب و زيانهاى ناشى از آن يكى از مسائل مطرح

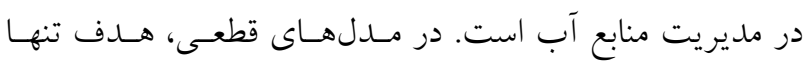

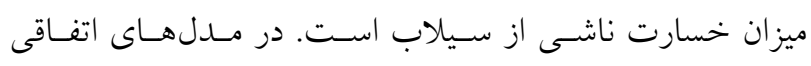
درست نمايى رخدادها نيز مورد توجه قرار مى گيرد. يـك آنـاليز

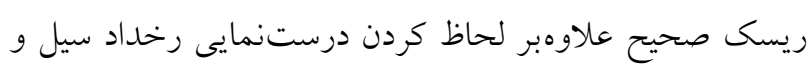

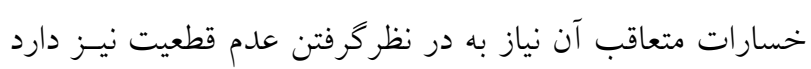

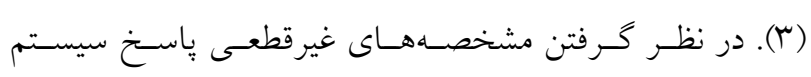

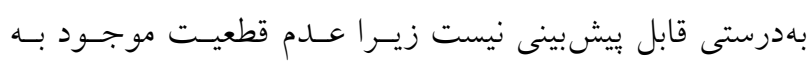

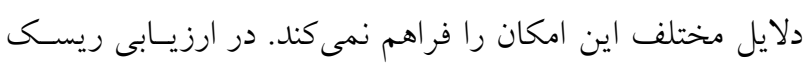

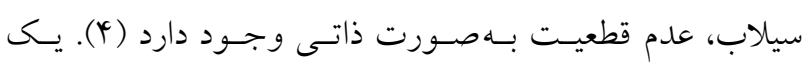
شاخص كليدى براى آناليز ريسك سيلاب، خسارت مورد فئس انتظار

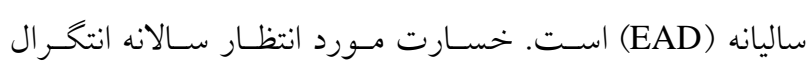

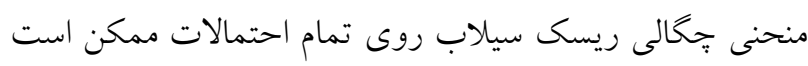

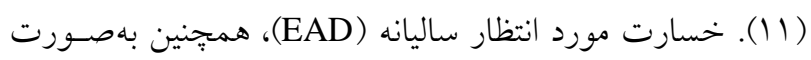

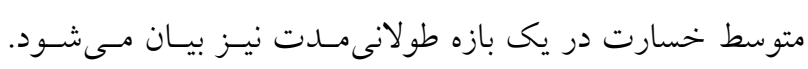

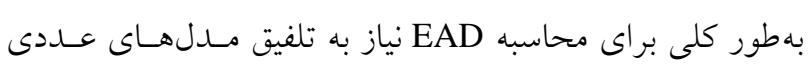

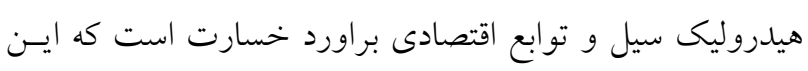

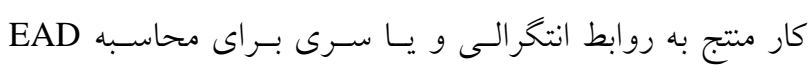

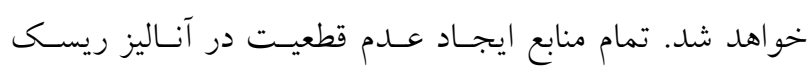

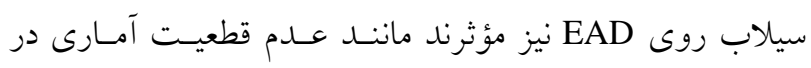

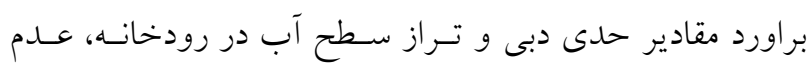

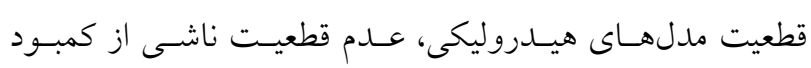

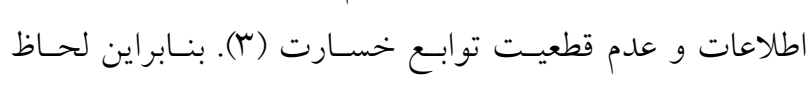

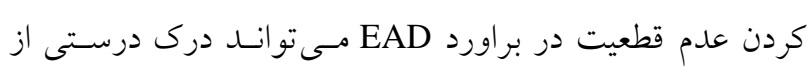

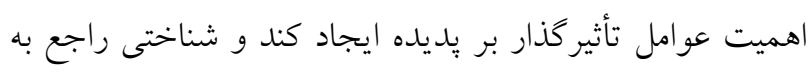

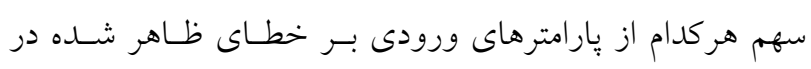
نتايج خروجى ارائه دهد.

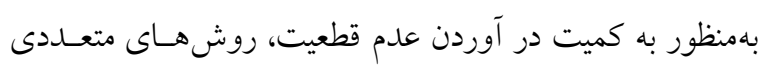

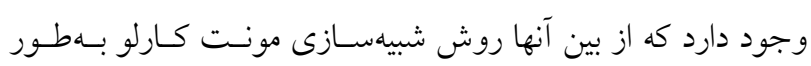

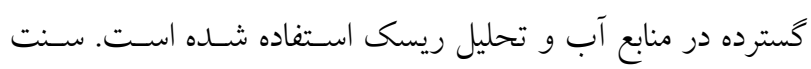
جورج و همكاران (11) بهمنظور رتبهبندى منـابع عـدم قطعيـت در درد 


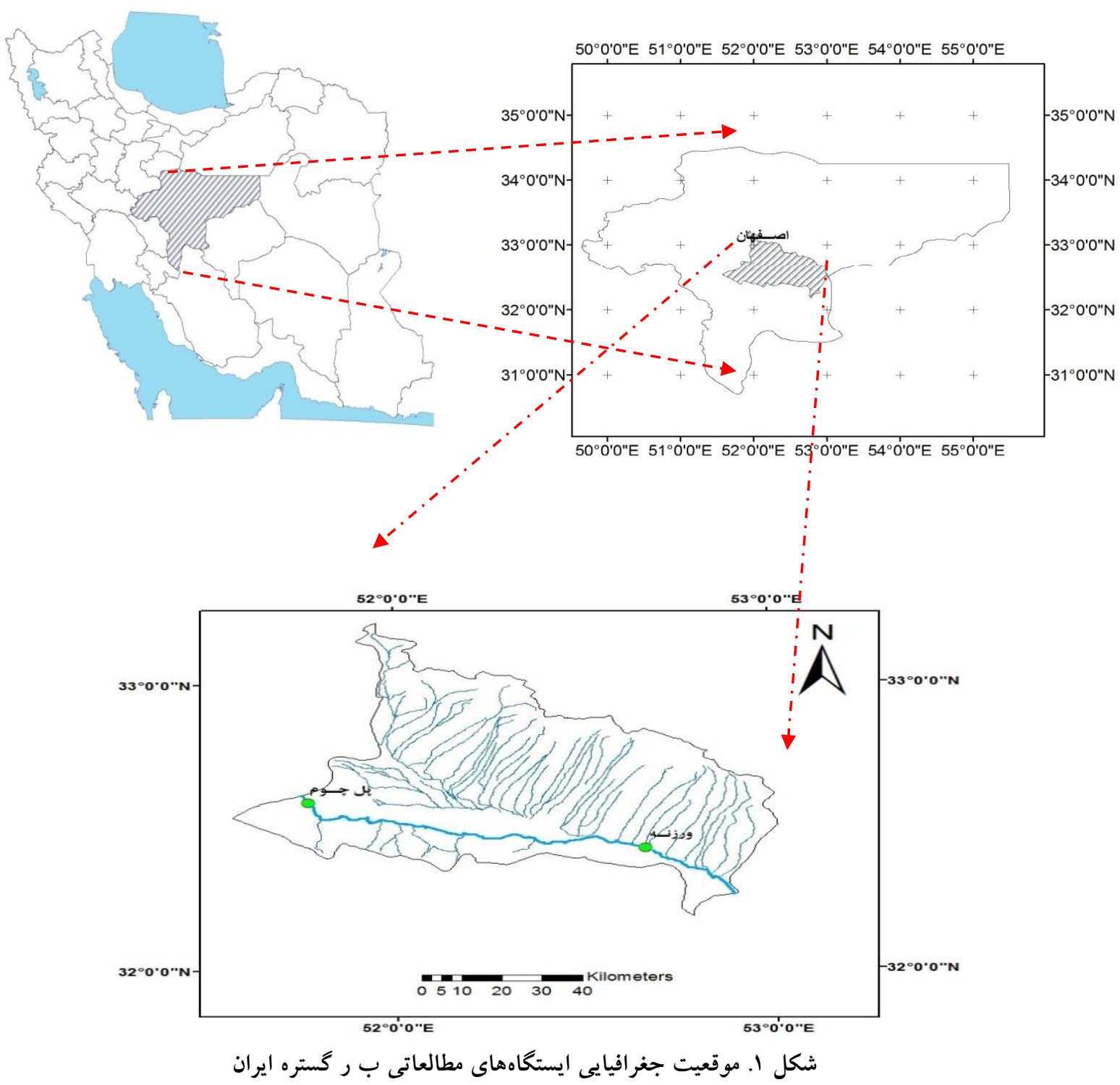

متعلق به آب منطقهاى با طول دوره آمارى OV سال انجـام شـده است. جدول (1) مشخصات ايستخاههاى مورد مطالعه را نشـان

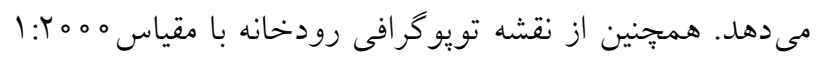
استفاده شده است. براورد خسارت مورد انتظار سيلاب در اين يزوهش براى براورد EAD از نتسايج تحليـل فراوانى سـيل

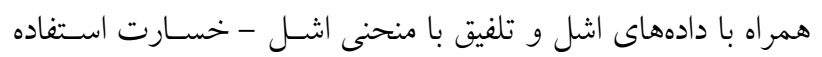

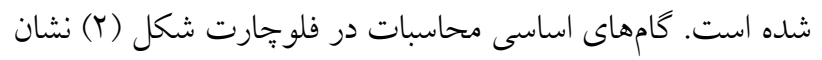

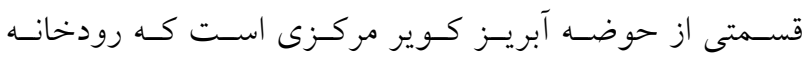

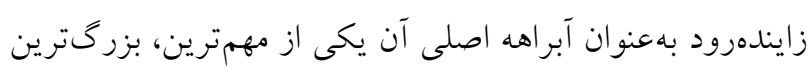

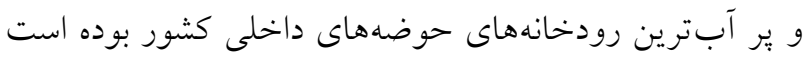
كه حوضه آبريز اصفهان و كاوخونى را زهكشى مسى كنــد و بــهـ

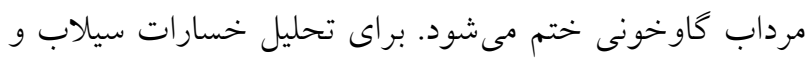

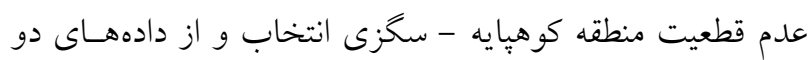
ايستخاه بِل جوم و ورزنه استفاد شده است. مشخصات حوضهـ در شكل (1) و جدول (1) مشخص شده است. در اين مطالعه.

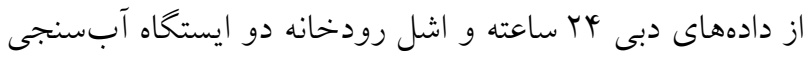


جدول ا. برخى از مشخصات ايستكاههاى مورد مطالعه حوضه آبريز گاوخونى

\begin{tabular}{|c|c|c|c|c|}
\hline ارتفاع & 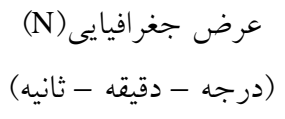 & 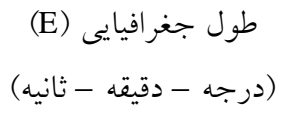 & نام حوضه & ايستخاه \\
\hline $100 \circ$ & $M T-M D-G$ & $|r / Q|-Y \varphi-Q$ & زايندهرود & يل جوم \\
\hline IFV。 & $r \Delta / r T-Y \Delta-\Lambda$ & $r q / \Delta r-r q-Q$ & زايندهرود & وزنه \\
\hline
\end{tabular}

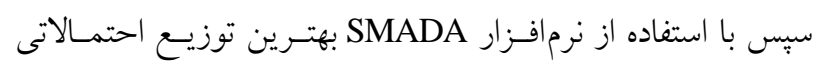

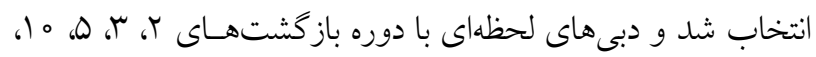

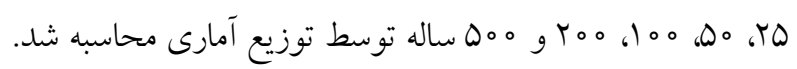

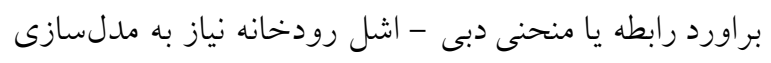

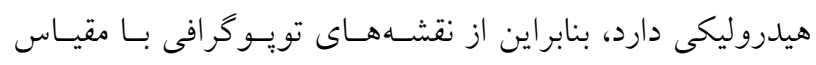

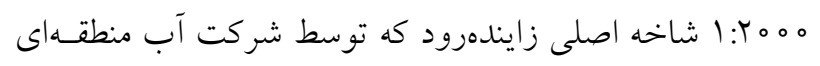

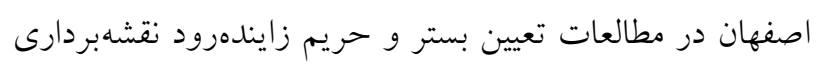

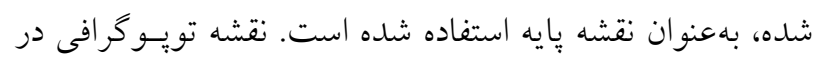

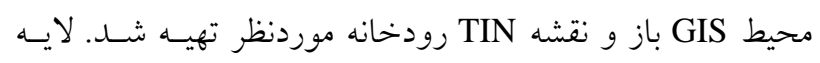
در واقع مبناى استخراج خطوط تراز و لايههـاى موردنيـاز HEC-GeoRAS است. در ادامه با استفاده از الحاقيه HEC-RAC به شبيهسازى هندسى رودخانه، لايههاى HEC-RAC در محسيط

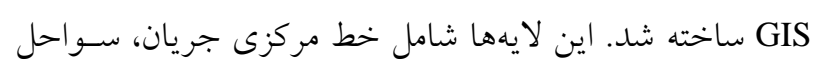

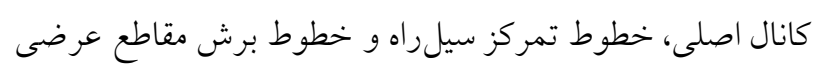

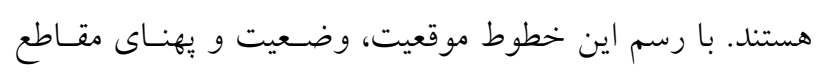

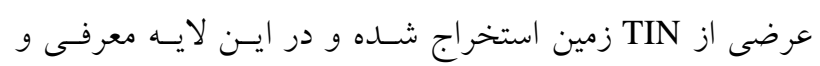

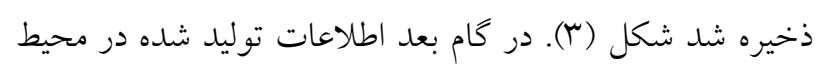

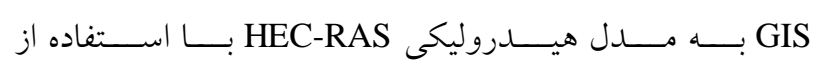
HEC-Geo RAS

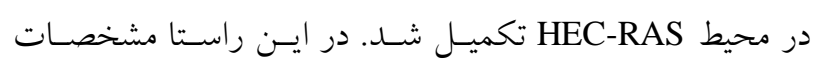

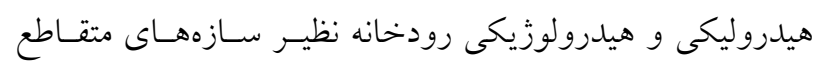

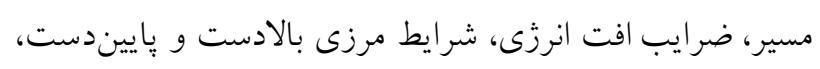

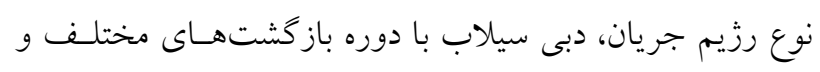

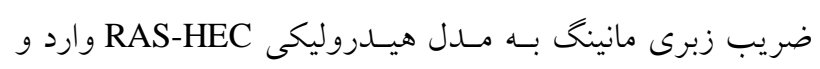

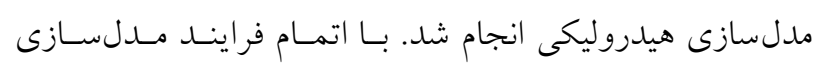

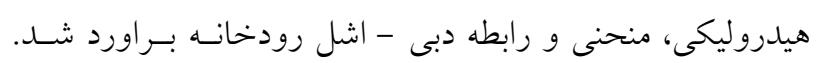

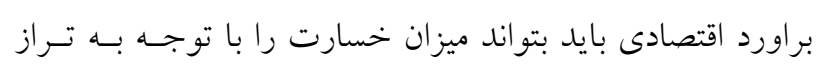

محاسبه جريان ورودى

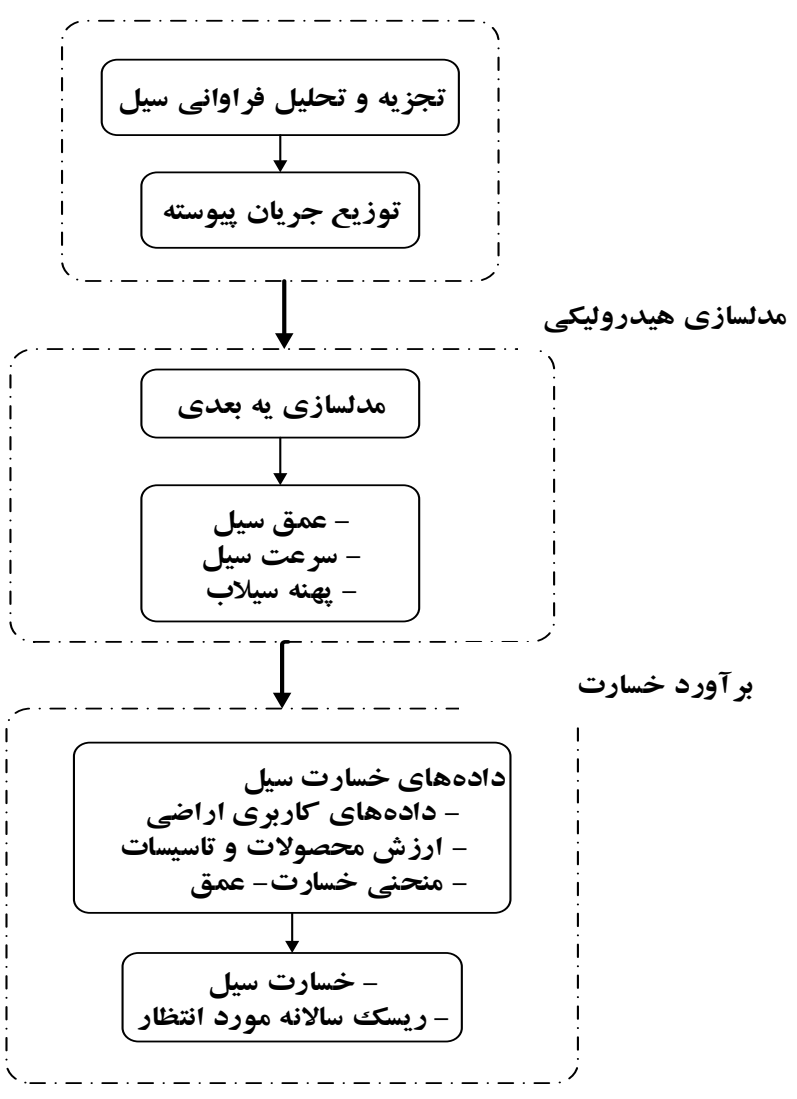

شكل r. الكوريتم كلى محاسبه خسارت مورد انتظار سالانه

داده شده است. ابتدا مدل هيدروليكى و مدل خسارت توضسيح داده

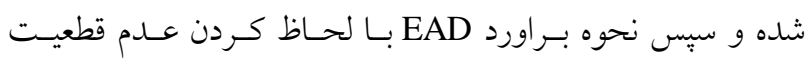
تشريح شده است.

مدلسازى هيدرولوزيكى - هيدروليكى و اقتصادى

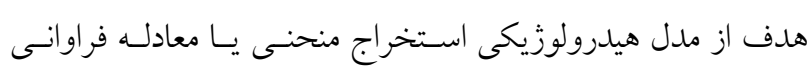

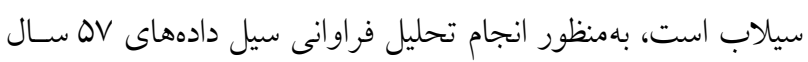
دبى حداكثر لحظهى ايستخاههاى هيدرومترى، تحليل همخنى نشده و 

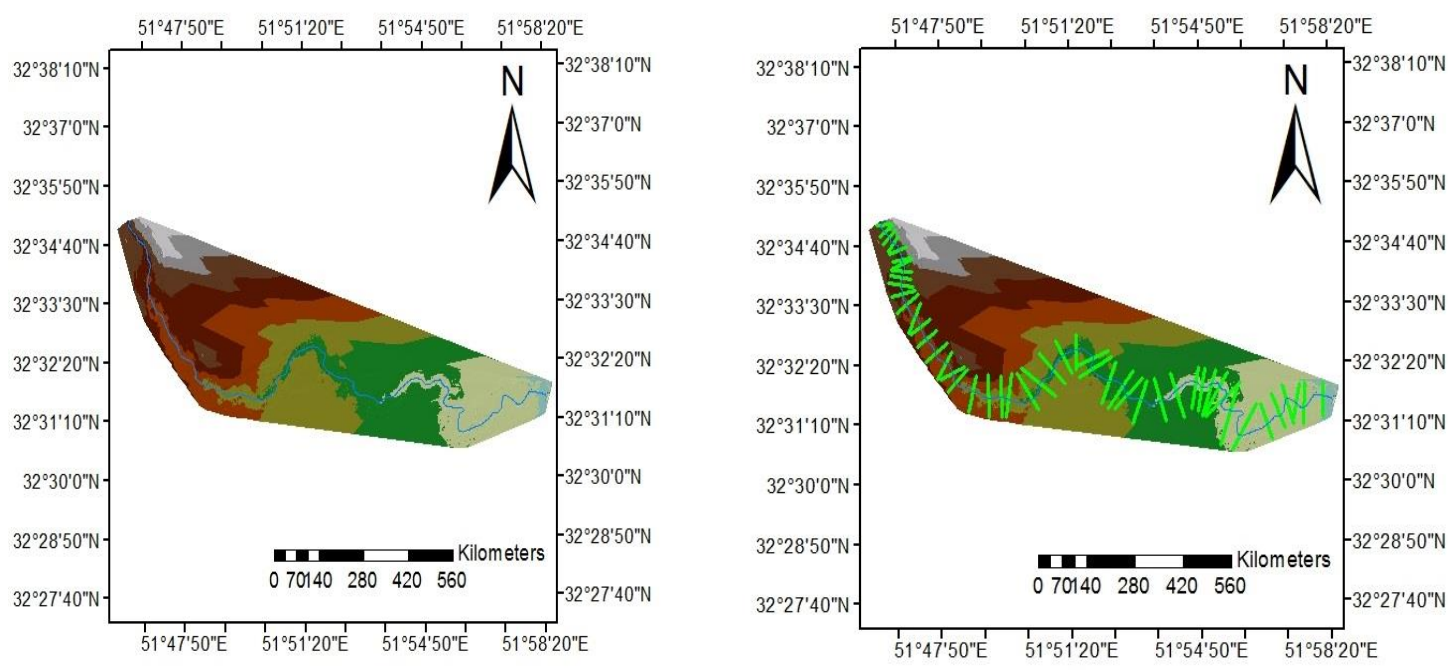

HEC-GeoRAs منكل r. نمونهاى از نمايش نقشه و خطوط مقاطع عرضى ايجاد شده در طول مسير رودخانه زايندهرود توسط

شكل (†) بعد از براورد نمودار احتمال رخداد - خسارت يـا CDF خسارت، مساحت زير اين نمودار همان EAD خواهد بود.

\section{بر اورد EAD}

تغييرات طبيعى سيل و نقص دانش هيدرولوزيكى و هيدروليكى از عوامل اصلى بروز عدم قطعيت در بـراورد EAD هسـتند. در براورد مقدار EAD به روش اتفاقى عدم قطعيـت لحساظ نشـــه است. شبيه سازى مونت كارلو بهعنوان يكى از روشهـاى آنـاليز كمّى ريسك معرفى شــه اسـت. در ايسن روش بـا توجـه بـهـ ويزگى هاى آمارى متغيرهاى تصادفى سيستم، بـراى هـر متغيـر بهصورت تصادفى يكى مقدار توليد شده و سيستم براساس ايسن مقادير توليد شده و مقادير متغيرهاى ورودى قطعى، بهصورت قطعى شبيهسازى مى شود. با تكرار زياد اين فرايند، ويزگى هـاى آمارى متغيرهاى خروجى جون ميانخين، انحراف معيسار و تـابع

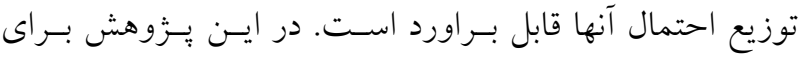
براورد EAD از آناليز مونت كارلو استفاده شـــه اسـت. بــر ايسن اساس احتمال وقوع تصادفى در بازه صفر و يك به تعداد هo 10

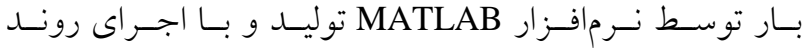
مدلسازى 00 ما خروجى خسارت حاصل شد، انحراف معيار، ميانخين خسارتها و ضريب تغييرات بارامتر خروجى محاسبه
سيلاب ييشبينى كند. با توجه به بهنهبندى سيلاب انجام شده و اطلاع از كاربرى اراضى اطراف منطقه مطالعـاتى، بــراى بـراورد خسارات ساليانه مورد انتظار به اراضى كشاورزى مقدار خسارات

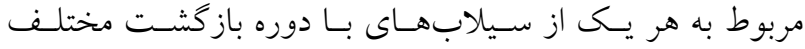

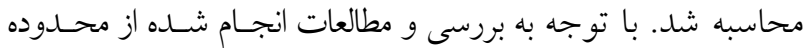
مطالعاتى بهطور متوسط در هر هكتـار از اراضسى مجـاور رودخانسه 99

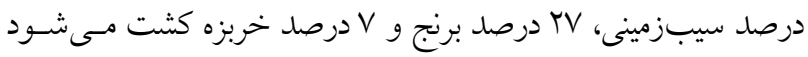
(جهاد كشاورزى اصفهان، اجس|). همجنين هزينه لاعرويسى بـراى هـر

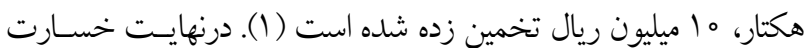

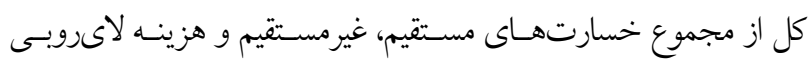

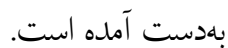

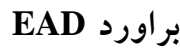
با استخراج منحنى فراوانى سيل، مىتوان منحنى دبى - اشل را توسط

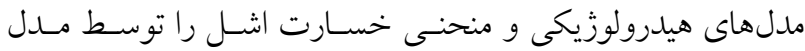
اقتصادى براورد كرد. سبس مىتوان مقدار EAD را به روش قطعى و با لحاظ كردن عدم قطعيتهاى موجود محاسبه كرد. برمبناى روش لرش

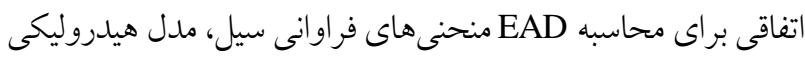
و براورد اقتصادى به كار كرفته مى شود. روند شـماتيكى محاسـبات

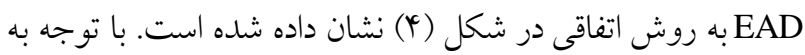




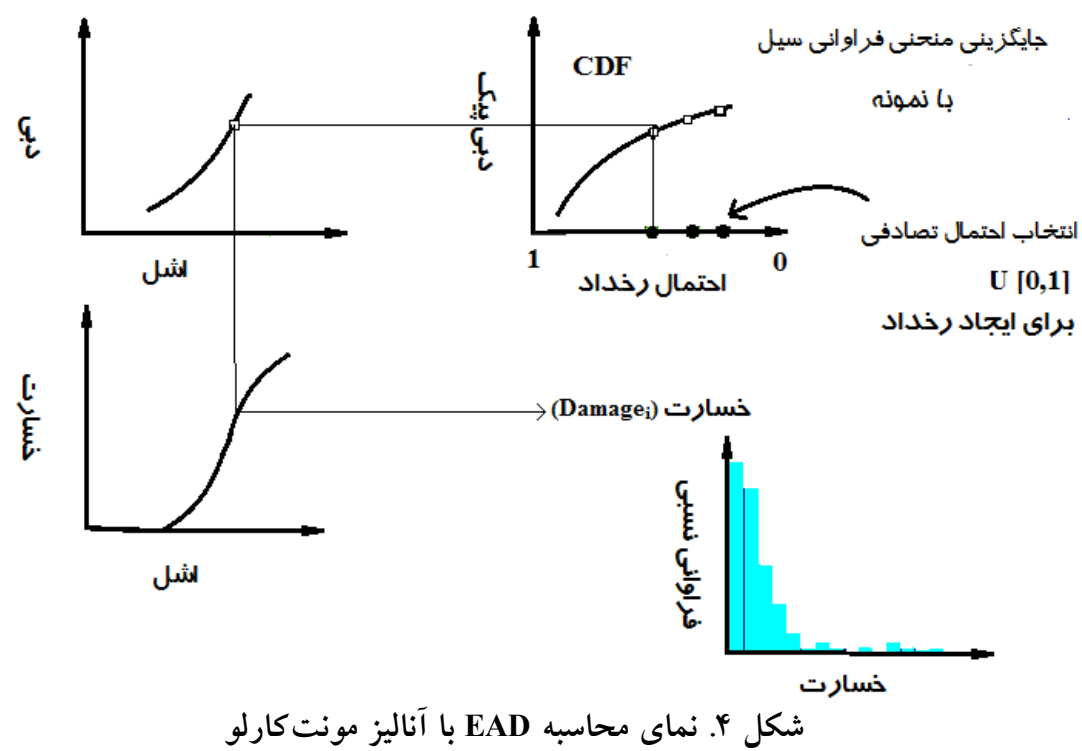

رخداد و براورد خسارت مرتبط با آن تا جايى ادامه مىيابد كـه

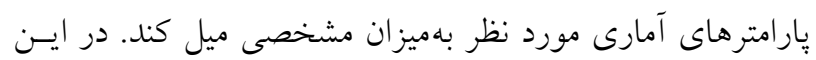
يزوهش متوسط خسارت و يك درصد احتمال تجاوز بـهنسوان

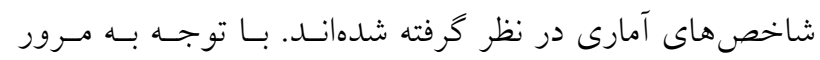
منابع، هزار تكرار براى رسيدن به همخر ايى كفايت مى كند شكل

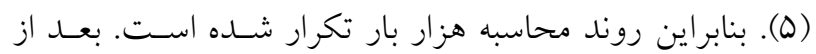

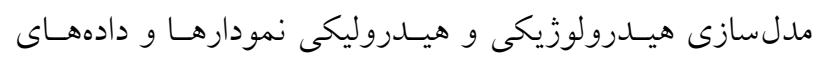

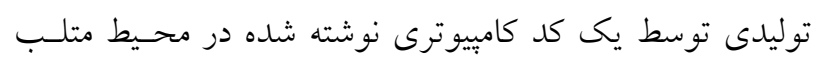

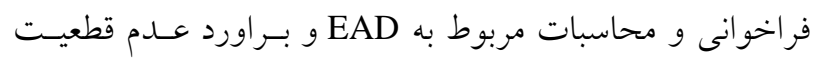
توسط كد كامييوترى محاسبه شده است.

\section{نتايج و بحث}

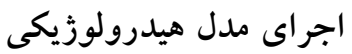

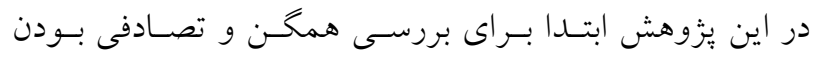

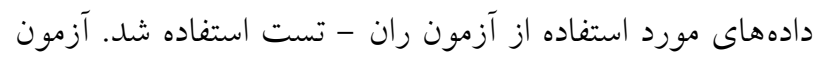

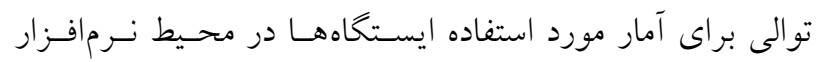

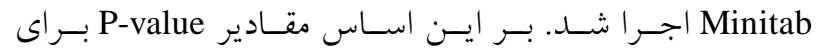
ايستخاههاى مطالعاتى 9/ه و 9/ه بهدست آمده با توجه به اينكه اين مقادير از ه/ه بزرگتر است (Y)، از صحت آمـارى دادههـا

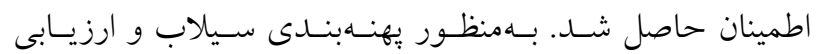

و بهعنوان معيار عدم قطعيت خروجى در نظر گرفته شد. بر اين

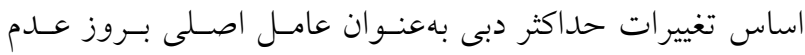
قطعيت تعيين شد. با اين وجود تخمين برخى بارامترها در مـدل

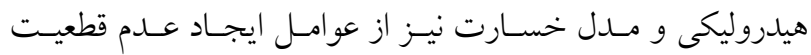

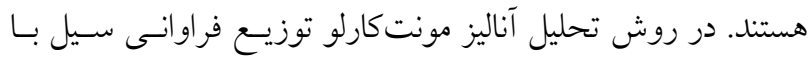

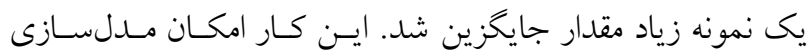

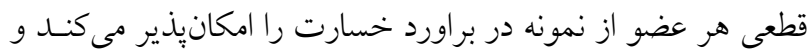

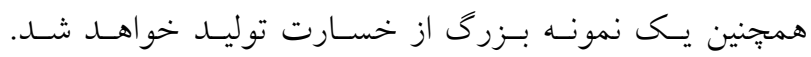

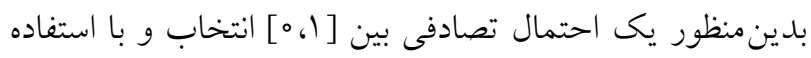

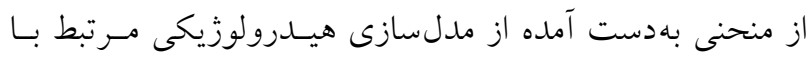

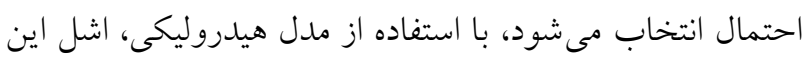

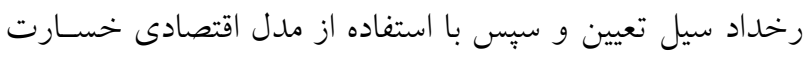

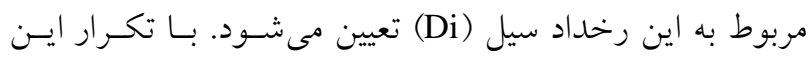
روند بهميزان لازم و تحليـل فراوانسى مقـادير خســارت، مقــدار EAD

$\mathrm{EAD}=\frac{1}{\mathrm{n}} \sum_{\mathrm{i}=1}^{\mathrm{n}} \mathrm{D}_{\mathrm{i}}$

كه درآن EAD خسارت مورد انتظار ساليانه و Di خسارت وارده بــه اراضى كشاورزى در اثر وقوع سيلاب i هستند. شكل (Y) شماتيكى از روند محاسبه EAD با روش مونت كارلو را نشان مىدهد.

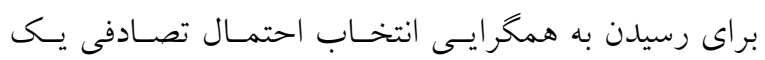



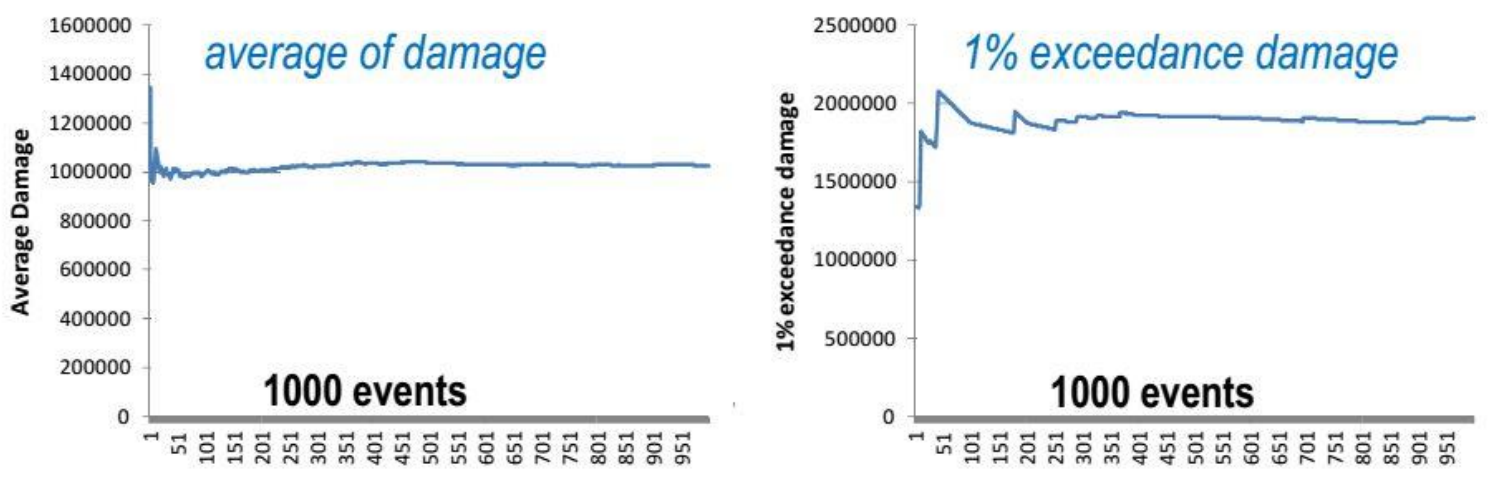

$$
\text { شكل ه. روند همخر ايى شاخصهاى آمارى بر اساس تكرار }
$$

جدول r. نتايج مقادير محاسبه شده سيلاب بهازاى دوره باز گثت مختلف

\begin{tabular}{|c|c|c|c|c|}
\hline انحراف استاندارد & مقدار محاسبهشده & دوره باز گشت & احتمال وقوع & رديف \\
\hline 10/T०KG & $90 / 1$ & r & $\circ / 0$ & 1 \\
\hline$|0 /||F|$ & $\Lambda 9 / \mu$ & r & $0 / 99 \mathrm{~V}$ & r \\
\hline TY/OYKY & ITH/V & 0 & $\circ / \Lambda$ & r \\
\hline YG/VQYA & $\mid \Lambda r / r q$ & 10 & $0 / 9$ & $\varphi$ \\
\hline 110/4 & TAV/AT & ro & $0 / 99$ & 0 \\
\hline 199/ArT & $r 90 / 9$ & ఎ. & $0 / 91$ & 9 \\
\hline$M 49 / 0094$ & $\Delta M G / T V$ & 100 & $0 / 99$ & v \\
\hline OVN/FYGA & VIN/IT & roo & $0 / 990$ & $\wedge$ \\
\hline $1099 / 904$ & $10 F T / K F$ & $\Delta \circ \circ$ & $0 / 991$ & 9 \\
\hline
\end{tabular}

\section{نتايج مدلسازى هيدروليكى}

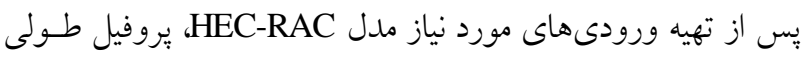

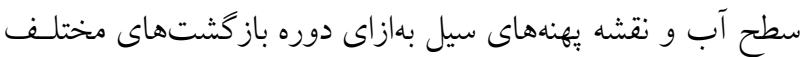

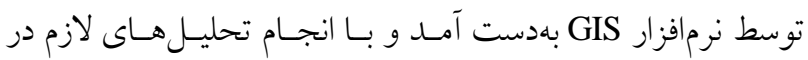
نرم|فزار GIS مساحت اراضى در يهنههاى سيل گير محاسبه شد. نظر

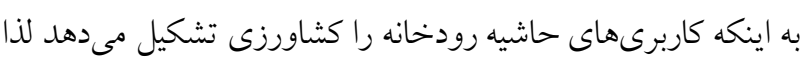

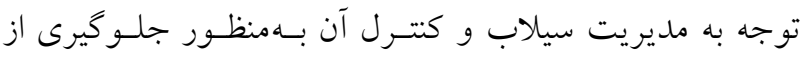
خسارت جبراننايذير بيش از بيش مشخص مسى شـود. در ايسن

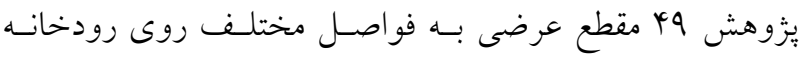

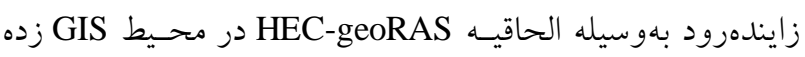
شده است، شكل (r). شكل (צ) نمونسهاى از مقـاطع عرضسى و

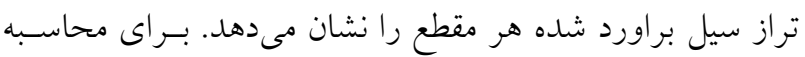

خسارت نياز به دبى بيكى ماهانه و سالانه با دوره باز گشتهـاى

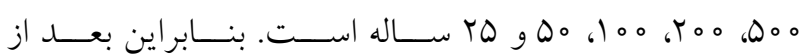
آماده سازى دادههاى دبى حداكثر سالانه از بين دادههاى تاريخى

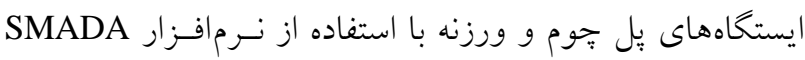

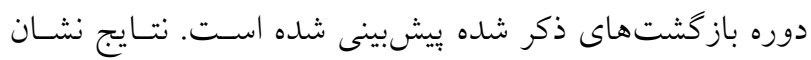
داد كه منحنى توزيع با منحنى دادههاى واقعى در توزيع لنَاريتم

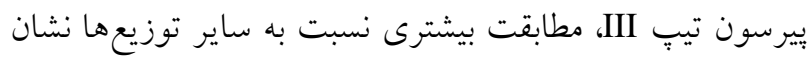

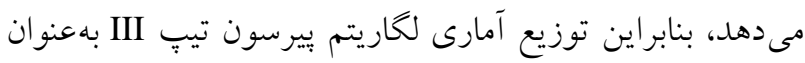
مناسبترين توزيع آمارى محدوده مورد مطالعه در نظـر كرفتسه

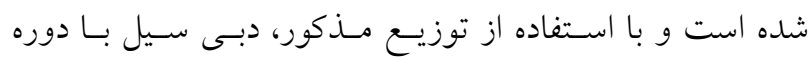

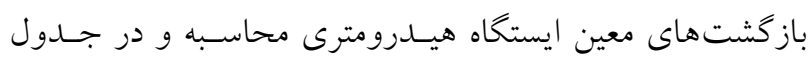

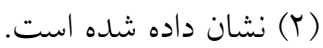



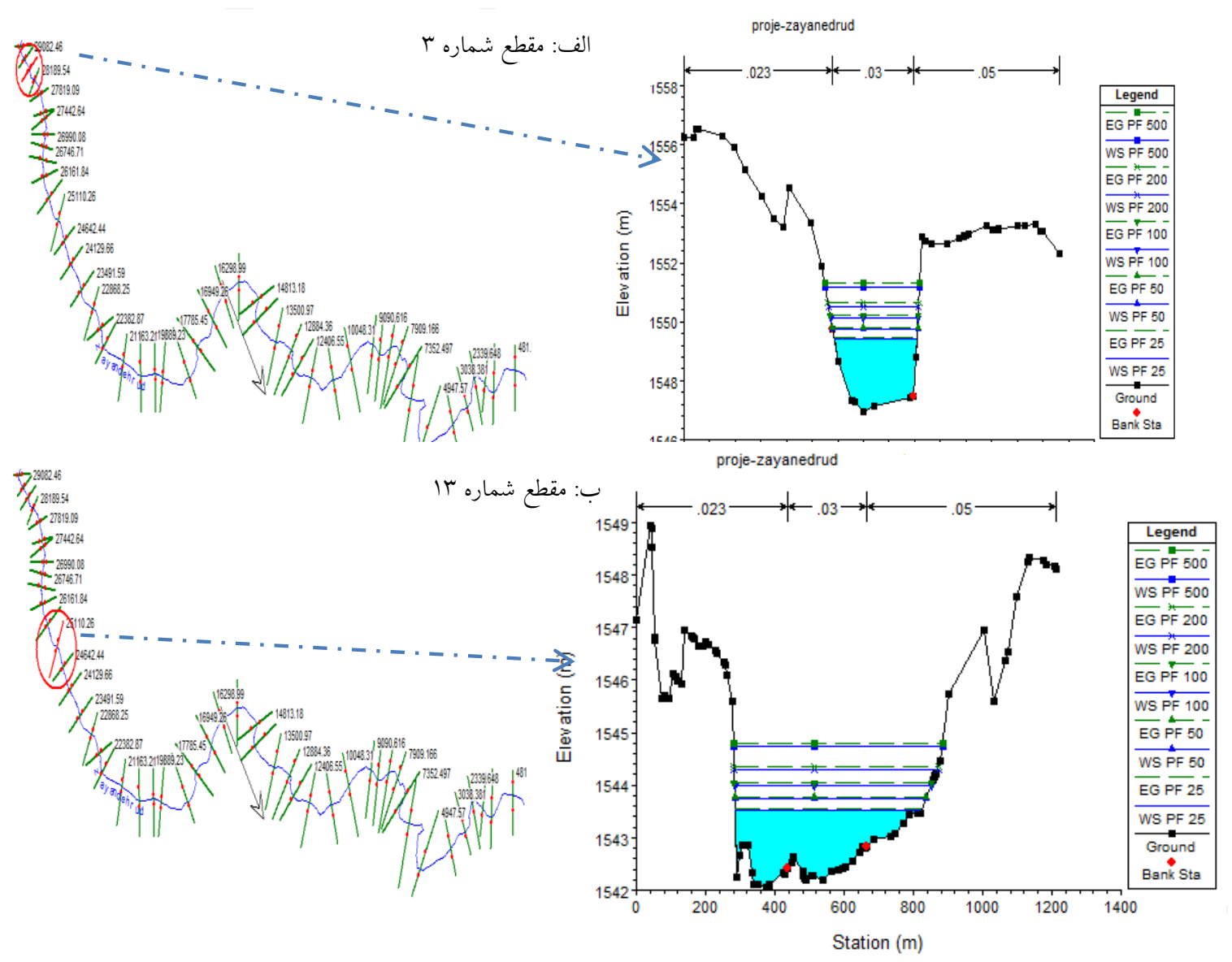

شكل 9. نمونه هايى از مقاطع عرضى رودخانه زايندهرود و نمايش سطح آزاد آب در هنخام وقوع سيل با دوره بازگثت مختلف

جدول r م نتايج بهنه سيلابى بهازاى دوره بازگشت مختلف

\begin{tabular}{|c|c|c|c|}
\hline دبى سيلاب (mr/sec) & مساحت خالص سيل گَرفتكى (هكتار) & دوره باز كشت & رديف \\
\hline$\Lambda r / r \Lambda \nu$ & $\Delta \wedge 9 \circ \Delta q / 1 \circ Y$ & rQ & 1 \\
\hline$r 90 / 9$ & VQVAVQI/IQT & ఎ. & $r$ \\
\hline TV/DHQ & NQQH०QT/rTr & 100 & r \\
\hline$|r / v| \Lambda$ & $94009 W / 000$ & roo & r \\
\hline$k y / l \circ k$ & $V 01 \mu T \Delta Q / V . q$ & Q०० & 0 \\
\hline
\end{tabular}

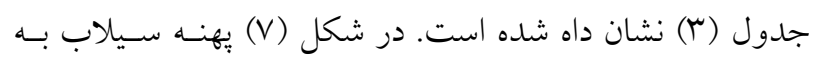

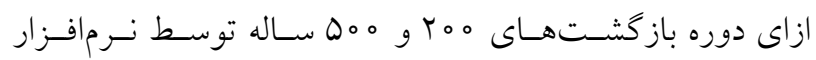
كو گل ارث در محيط واقعى زمين، بـهـعنـوان نمونسه نشـان داده

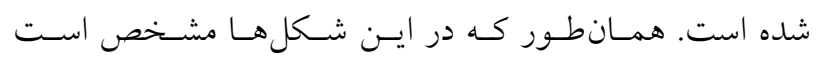
زمينهاى اطراف رودخانه داراى كاربرى كشاورزى و بيشـترين

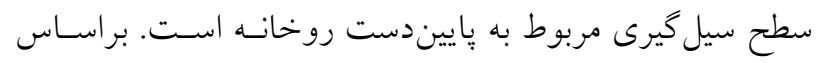

سطح اراضى مستـغرق در اثـر سـيلاب، سـطح سـيل گرفتخى بهازاى هر سال با سيستم اطلاعات جغرافيسايى (GIS) محاسـبه

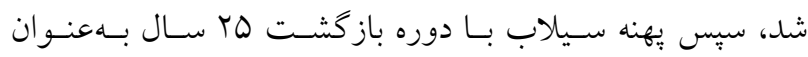

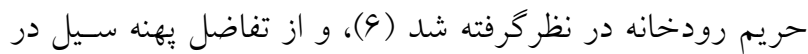
هر يك از مساحتهاى تعريف شــه بـا بهنـه سـيل TQ سـاله،

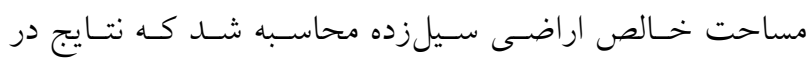



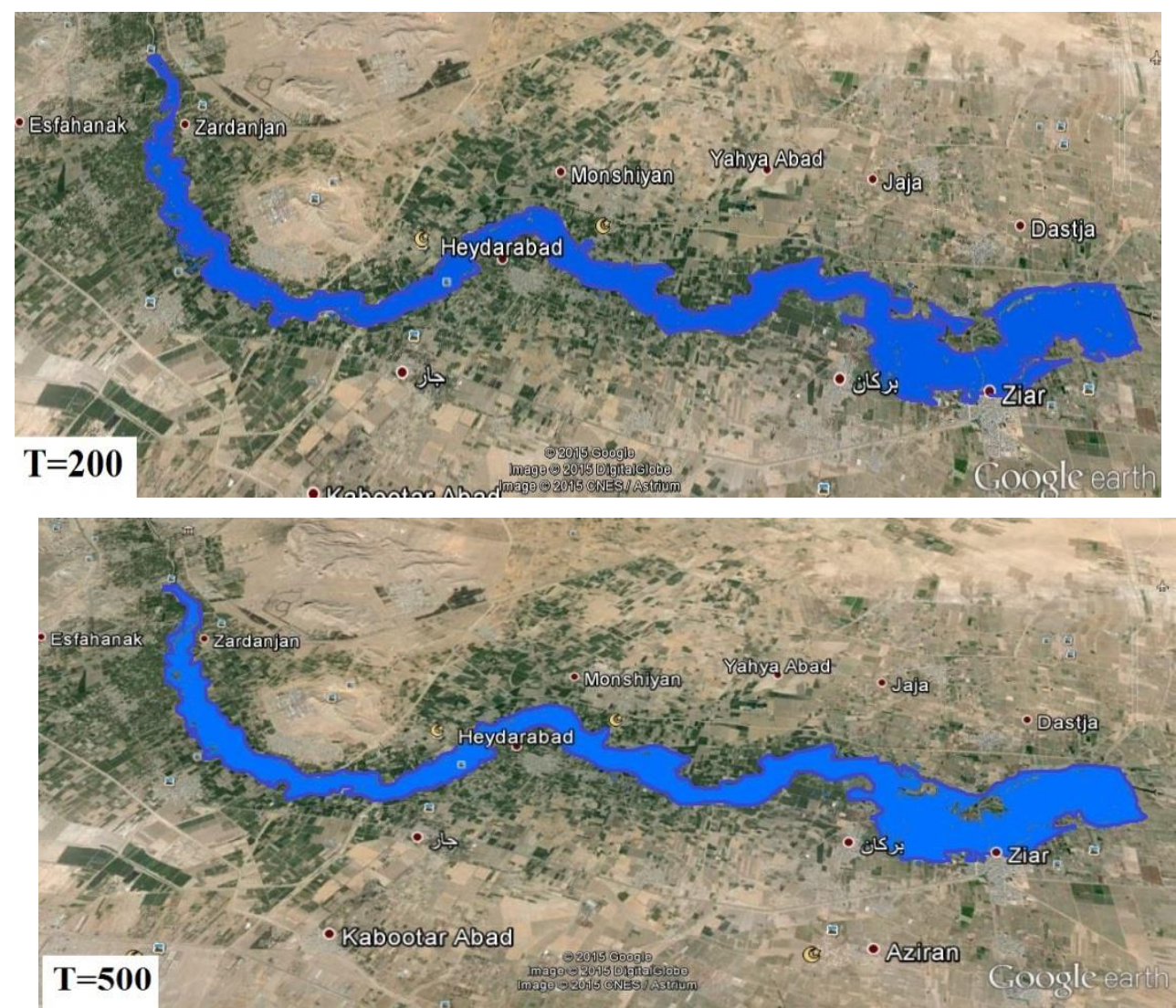

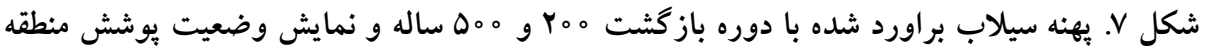

نشان داد كه دبى سالانه در تعيين عدم اطمينـان خسـارت داراى بيشترين اهميت است و علدم قطعيت خسارت نقـش عمــده در عدم قطعيت كلى را داراسـت. كـد كـامييوترى نوشـته شـده در محيط متلب بعد از فراخوانى دادهاى مدلهاى هيدرولوزيكى و هيدروليكى روند محاسبات EAD را بــر اسـاس روش توضسيح داده شده انجام داده و مقادير شـاخصهـاى آمـارى را محاسـبه مى كند كه در جدول (ه) نشان داده شده است.

\section{نتيجه گيرى}

در مطالعات هيدروليكى و هيدرولوزيكى علاوهبر مقادير نهـايى محاسبه شده نحــوه مــل سـازى يديــده (قطعى، احتمـالاتى و اتفاقى) به اندازه خود نتيجـهـ مهـم اسـت. در ايسن يـرَوهش بـه بررسى ريسك سيلاب رودخانه با در نظر كرفتن عـدم قطعيـت يرداخته شده است. بدينمنظور براى تحليل آمارى و مدلسازى
نقشه يُهنهاى سيل، نمودار تغييرات مساحت يهنه سيلاب با دوره باز گشتهاى مختلف آن در شكل (N) نشان داده شده است.

براورد خسارت مــورد انتظـار سـاليانه (EAD) بـه اراضسى كشاورزى منطقه

جدول (Y) نتايج حاصل از خسارت بهازاى دوره باز گشت هاى مختلف را نشان مى دهد. شكل (9) نيز روند تغييرات خسـارت كل در مقابل دوره بازگشت را نشان مىدهد.

نتايج تحليل عدم قطعيت در براورد خســارت بـا اسـتفاده از روش مونت كارلو

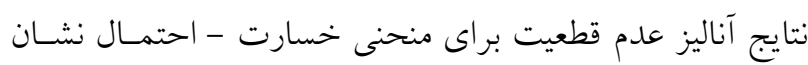

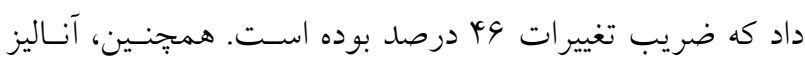
عدم قطعيت خسارت با در نظـر گـرفتن اثـر تركيبى بارامترهـا 


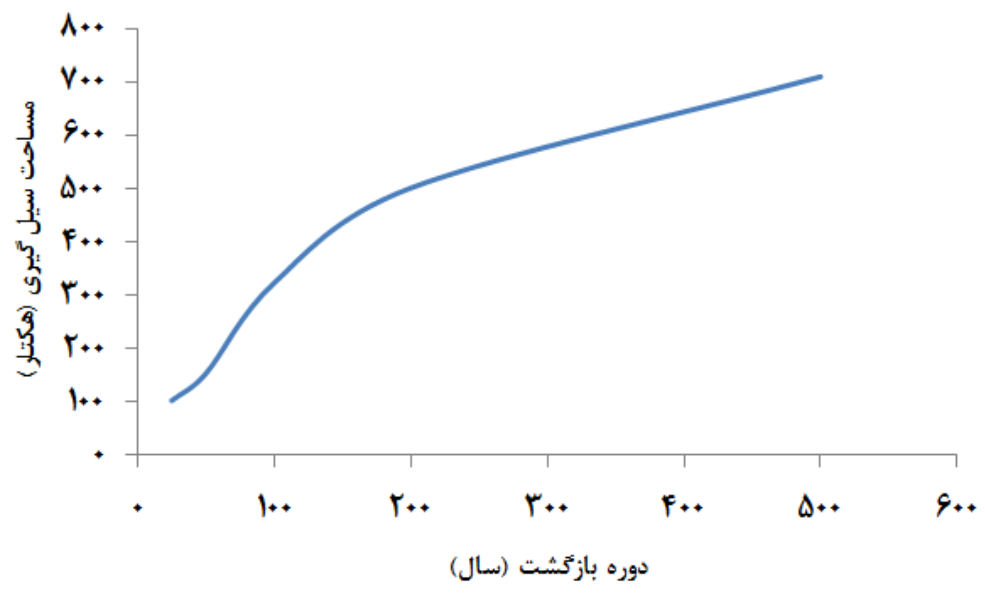

شكل ^. تغييرات مساحت يهنه سيلاب بهازاى دوره بازگشت مختلف بازتس

جدول fا. مقادير خسارات مربوط به عمقهاى سيل گيرى در دوره باز گشتهاى مختلف

\begin{tabular}{|c|c|c|c|c|c|c|}
\hline خسارت كل & خسارت لاىروبى & 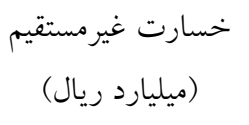 & خسارت مستقيم & عمق سيل كيرى & دوره باز گشت & رديف \\
\hline- & - & - & - & $1 / V 0$ & TQ & 1 \\
\hline lQY $/ \Lambda \circ \Lambda$ & IOT/VQV & 199/VIT & ৭৭N/DG & T/VV & Q. & r \\
\hline TYM/OVA & MTY/AGD & KYY/l०V & $r \mid 1 / \circ \Delta r$ & $r / l r$ & 100 & r \\
\hline $0.1 / 091$ & $0 \circ \circ / 94 \circ$ & $904 / 919$ & TTV/FDQ & $r / \Delta \Delta$ & roo & t \\
\hline$V I Y / \circ Y Q$ & $v \circ q / v \circ 1$ & QRV/AYq & FGM/QYY & $Y / I V$ & Q०० & 0 \\
\hline
\end{tabular}

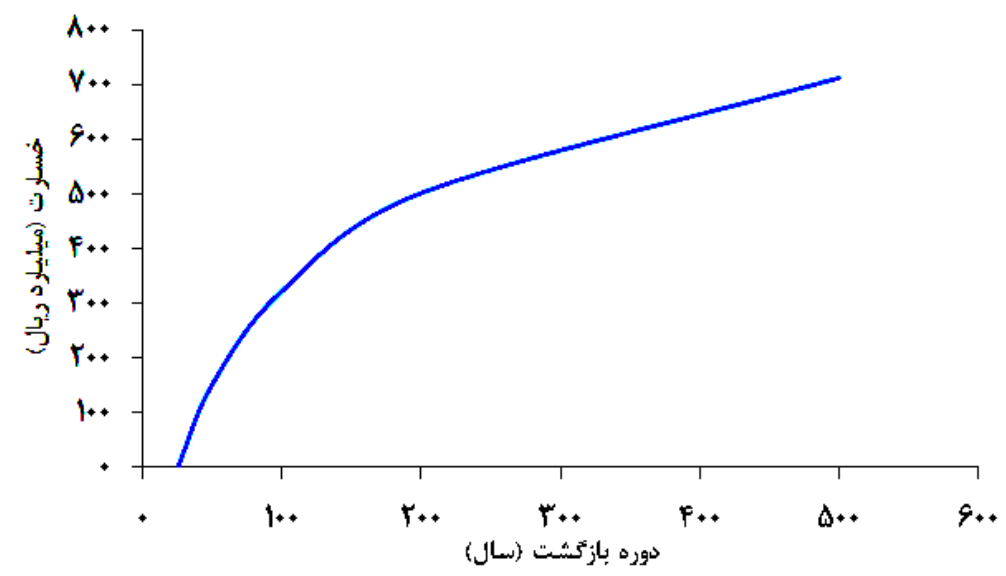

شكل 9.

هيدرولوزيكى محدوده مطالعـاتى از نـرمافـزارSMADA، بــاى منطقه كوهيايه - سكزى از حوضه آبريز زايندهرود براى بررسى

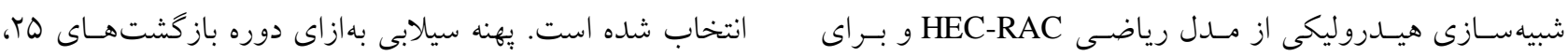

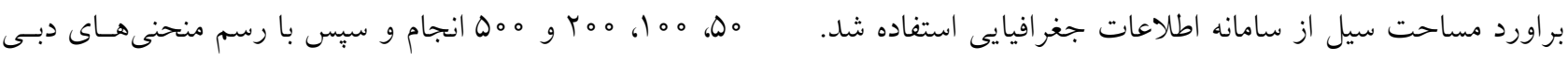




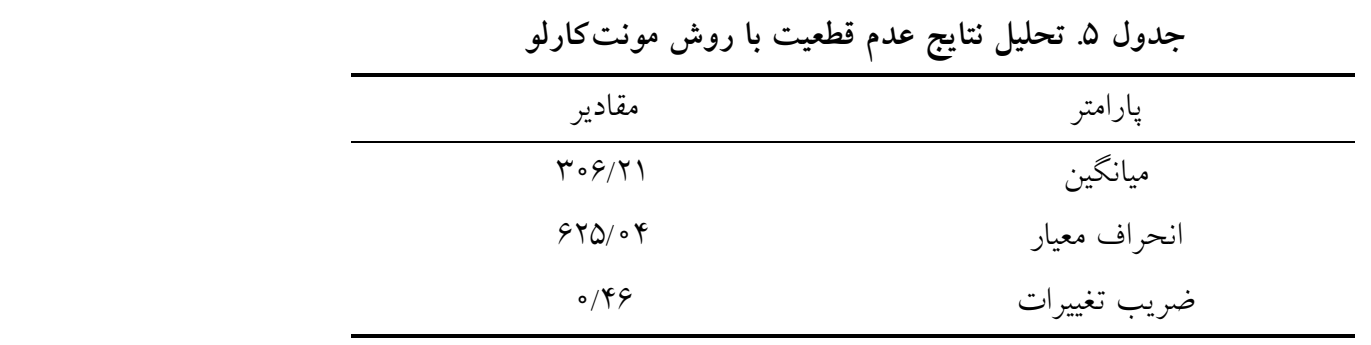

خسارت مورد انتظار سالانه (EAD) محاسبه و نتايج آناليز عـدم

قطعيت براى منحنى خسارت -احتمـال نشـان داد كـه ضـريب

تغييرات و4 درصد بوده است كه نشاندهنده تأثير قابـل بـراورد

دبى حداكثر (نتايج مدل هيدرولوزيكى) در محاسبه EAD است.

در اين يزوهش عدم قطعيت مربوط به مدلهــاى هيـدروليكى و

مدل اقتصادى بررسى نشده است و رفتار هيدروليكى و بــراورد

خسارت بهصورت قطعى در اين مطالعه ديده شده است.
يّيك - احتمال وقوع، دبى - اشل و اشل - خسارت براى منطقه مطالعاتى، تابع احتمال وقوع خسـارت بـهدسـت آمـــ و ميـزان خسارت سيلاب با دوره باز گشت مختلف محاسـبه شـد. نتـايج نشان داد كه بيشترين سيلاب و خسـارت بـراى دوره باز گشـت

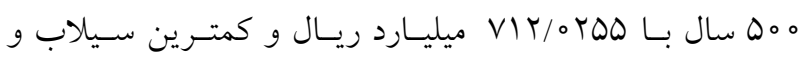

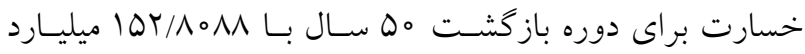

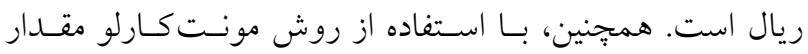

\section{منابع مورد استفاده}

1. Alizadeh, A. 2010. Principles of Applied Hyudrology. $25^{\text {th }}$ Edition. Ferdowsi University of Mashahd Publisher, I.R. Iran. (In Farsi).

2. Bashiri Atrabi, H. 2012. Optimum operation of dam reservoir based on flood risk management with HS method. Master thesis, Shahid Bahonar University, Kerman, I.R. Iran. (In Farsi).

3. Beven, K. and J. Hall. 2014. Applied Uncertainty Analysis for Flood Risk Management. Imperial College Press. London.

4. Delenne, C., B. Cappelaere and V. Guinot. 2012. Uncertainty analysis of river flooding and dam failure risks using local sensitivity computations. Reliability Engineering and System Safety 107(11): 171-183.

5. Faber, B. 2014. Flood Risk Analysis considering 2 types of uncertainty. US Army Corps of Engineers Institute for Water Resources Hydrologic Engineering Center, Hydrologic Engineering Center, US.

6. Ghanjalikhani, M. 2014. Assesment of Copula Functions in prediction of groundwater quality (Case study: Kerman Aquifer). MSc. Thesis, Shahid Bahonar University, Kerman, Iran. (In Farsi).

7. Kalyanapu, A. J., D. R. Judi and T. N. McPherson. 2014. Annualized risk analysis approach to recommend appropriate level of flood control: application to Swannanoa river watershed. Journal of Flood Risk Management 15(3): 1-18.

8. Ministry of Power Publication. 2005. Flood damage assessment. Publication No. 296, Tehran. Iran (In Farsi).

9. Olsen, A., Q. Zhou, J. J. Linde and A. Nielsen. 2015. Comparing methods of calculating expected annual damage in urban pluvial flood risk assessments. Water 7(3):255-270.

10. Razaghe Rad, B. 2011. Flood zoning for different return period using GIS analysis. Master thesis, Graduate University of Advanced Technology, Kerman, Iran. (In Farsi).

11. Sargent D. M. 1992. Flood management in rock Hampton. In: Proceeding of the International Conference on Floods and Flood Management, Italy.

12. Saint-Geours, N., F. Grelot, J. S. Bailly and C. Lavergne. 2015. Ranking sources of uncertainty in flood damage modelling: a case study on the cost-benefit analysis of a flood mitigation project in the Orb Delta, France. Journal of Flood Risk Management 8(5):161-176.

13. Yakhshaki, M., M., A. Meftah, M. Zahirie, A. Yakhshaki and M. Madadi. 2014. The result of nrmab dam construction in reduce of downstream flood damage. Irrigation Engineering and Water Journal 4(16): 24-36. (In Farsi). 


\title{
Uncertainty Analysis of Expected Annual Flood Damage for Flood Risk Assessment (A Case Study: Zayande Roud Basin)
}

\author{
N. Alian, M. M. Ahmadi* and B. Bakhtiari ${ }^{1}$
}

(Received: September 13-2017; Accepted: August 18-2018)

\begin{abstract}
One of the most important problems in flood manegment is the damages induced by this phenomenon. Expected annual damage (EAD) is an important index for basin vulnerability against flood. Prediction of flood damages requires the analysis of spatial and temporal risk and must be calculated by the combination of hydrologic, hydraulic and economic models. In this research, the uncertainty was considered in the flood risk analysis. The probability of flood occurrence was calculated by the parabolistic model. By using the river analysis systems software (HEC-RAS) and the geographic information system (GIS) and utilizing the Google-Earth software, the floodplains of Zayande Roud river in Esfahan province were investigated with the return period of 25, 50, 100, 200 and 500 years. The Monte Carlo method was also sed to perform the uncertainty analysis in the proposed method. The logarithmic persion type III was selected as the best distribution of flood. The damage-stage relationship was calculated as well. Based on the uncertinity analysis, the river discharge could be regarded as the major parameter in the uncertainty of EAD.
\end{abstract}

Keywords: Risk, Flood damages, HEC-RAS, GIS, Uncertainty, Kohpaye-Seqzie, Zayande Roud

1. Water Science and Engineering Department, Faculty of Agriculture, Shahid Bahonar University of Kerman, Kerman, Iran.

*: Corresponding Author, Email: ahmadi_mm@uk.ac.ir 